\title{
Wading into the undeniable
}

\author{
Stephanie Keep, Ann Reid and Glenn Branch ${ }^{*}$
}

\begin{abstract}
In his review of Bill Nye's Undeniable, Nicholas Wade proposes a "treaty" to defuse controversies over the teaching of evolution: describing evolution as a theory ambiguously - as a well-established scientific theory to supporters of evolution education, but as "just a theory" to opponents of evolution education. On inspection, Wade's proposal misidentifies the focus of the creationist objection to evolution, distorts the nature of science, and involves a blatant equivocation. Rather than equivocating on the term theory à la Wade, teachers ought to focus on ensuring that students understand not only the important theories in the field of evolutionary biology but also what a theory in science is and isn't.
\end{abstract}

Keywords: Teaching evolution; Bill Nye; Nicholas Wade; Nature of science

Is there a simple and easy way to defuse controversies over the teaching of evolution? Nicholas Wade apparently thinks so. In the course of his review for The Wall Street Journal of Undeniable-a popular book on evolution by Bill Nye, the beloved "Science Guy" of educational television in the 1990s who is now reinventing himself as a crusader for science education-Wade proposes a "treaty" between science and fundamentalism, which he thinks will resolve the nearly century-long conflict between those who want evolution to be taught forthrightly and those who seek for the topic to be banned, balanced, or belittled. Unfortunately, on inspection, the proposal is deeply flawed.

Wade applauds Undeniable for making "an eloquent case for evolution," but correctly notes that, with regard to creationists, "Nye's fusillade won't budge them an inch" (Wade 2014). There is ample evidence that facts are not enough to sway those who reject evolution for ideological reasons: facts are necessary, to be sure, but they are not sufficient. ${ }^{\text {a }}$ Wade then wonders, "Isn't there some more effective way of persuading fundamentalists to desist from opposing the teaching of evolution?" (Wade 2014). The wish to find a more effective way of decreasing opposition to the teaching of evolution is, of course, commendable.

What is not so commendable, however, is Wade's proposal for doing so. He suggests, "it would be easy enough

\footnotetext{
* Correspondence: branch@ncse.com

National Center for Science Education, PO Box 9477, Berkeley, CA 94709-0477, USA
}

to devise a treaty that each could interpret as it wished. In the case of teaching evolution in schools, scientists would concede that evolution is a theory, which indeed it is. Fundamentalists might then be willing to let their children be taught evolution, telling them it is "just a theory" (Wade 2014). The "just a theory" slogan dates back to the Scopes era, of course, but it is still prevalent: in 2012, for example, New Hampshire's House Bill 1148 would have required the state's public schools to disparage evolution by teaching it "as a theory."

To his credit, Wade understands the scientific use of the term theory. He is not proposing the teaching of evolution as "just a theory" - as something conjectural or speculative, a guess or a hunch (Branch and Mead 2008). Rather, he describes evolution accurately as "no casual surmise but a theory in the solemn scientific sense, a grand explanatory system that accounts for a vast range of phenomena and is in turn supported by them. Like all scientific theories, however, it is not an absolute, final truth because theories are always subject to change and emendation" (Wade 2014). But there are at least three grave problems with his attempt to broker a treaty on evolution.

First, the proposal would be ineffective, for Wade misunderstands the focus of creationist objections to evolution. How so? When he recommends that evolution be taught as a theory, he distinguishes "between evolution as a historical process, which is undeniable, and evolution as a scientific theory" (Wade 2014). Indeed, it is frequently observed (by, for example, Gould 1981; 
Ruse 1984; Gregory 2008) that it is important to distinguish between claims about the fact (which Wade calls, misleadingly, the "historical process") of evolution and theories about-that is, systematic explanations of-the paths and processes of evolution.

The distinction Wade urges is valid, but it is wrong to think that it helps to allay the concerns of creationists about the teaching of evolution. Although creationists have various objections to claims about the paths and the processes of evolution, it is not the details of genuine controversies within evolution, such as kin selection versus group selection, that motivate creationist assaults on the teaching of evolution. Indeed, supporters of the teaching of evolution have no objection in principle to airing such controversies in the public schools, although judiciousness in the selection is required (Berbeco et al. 2014).

Rather, it is common descent-the big idea of evolution-that is the primary target of creationist attacks on science education. Common descent-especially as it pertains to humans sharing their ancestry with the rest of life-has consistently been at the center of creationist activism, even as the goals have shifted from banning the teaching of evolution, to balancing the teaching of evolution with that of biblical creationism, creation science, or intelligent design, to requiring or encouraging teachers to belittle evolution as scientifically controversial (Branch et al. 2010). ${ }^{\mathrm{b}}$ But common descent is precisely the "historical process" that Wade characterizes as "undeniable."

Second, Wade's proposal dangerously distorts the nature of science. A sign of the distortion can be detected in his recommendation to distinguish evolution as undeniable fact from evolution as theory. The latter, he adds, "is not inscribed unalterably on stone tablets but is still very much a work in progress" (Wade 2014), thereby suggesting that the former is final, unrevisable, and absolute. In fact, nothing in science is final, unrevisable, and absolute: putative facts as well as theories are subject to revision in the light of further evidence and theory. (The title of Nye's book is a pun on the author's surname-UndeNYEable-not a literal description of evolution).

To see the problem, consider the question: What would Wade have biology teachers and textbooks do differently? Apparently, he would have them present the fact of evolution-common descent-as inscribed unalterably on stone tablets, final, unrevisable, and absolute. That is bad advice: they should present it as responsible teachers generally do, as a well-established fact, revisable in principle but in actuality supported by overwhelming evidence. Wade would apparently also have them present claims about evolutionary paths and processes as "scientific theories" and as "works in progress." That is good advice: but, of course, responsible teachers already generally present such claims in that way.

Third, Wade's proposal is for a strategy that is arguably dishonest. He is in effect urging supporters of evolution education to engage in a transparently disingenuous and blatantly equivocating campaign, telling creationists that evolution is "just a theory" out of one side of their mouths and singing its praises as a grand unifying explanation out of the other. Surely a responsible teacher will want to think twice about adopting such a strategy. Moreover, even those without qualms about engaging in unethical behavior for the sake of a good cause, decreasing opposition to the teaching of evolution, are likely to realize that such a strategy will be easily detected and rejected.

The specific flaws in Wade's proposal aside, the idea that there is a simple and easy way to defuse controversies over the teaching of evolution was implausible from the outset. When it comes to such a complex and persistent conflict, involving not only science and religion but also education, law, and politics, all interacting in a dynamic web over the last century, no one-size-fits-all resolution is likely to be in the offing. Although there are signs of progress-for example, the general improvement in the treatment of evolution in state science standards over the last fifteen years-it is clear that evolution will continue to be contentious in American science education for years to come.

So what is a science educator to do? Part of the solution is emphasizing the nature of science. Nye's understanding of the nature of science evidently surpasses Wade's. In the first chapter of Undeniable, he advocates incorporating instruction on the nature of science into the study of evolution, recommending that evolution be taught historically as "a compelling case study of the collaborative and cumulative way that great scientific discoveries are made" (Nye 2014, p. 5). Yet although evolution lends itself to a historical approach, it ought not to be the only topic to receive such a treatment, lest students come to think that the rigorous testing and retesting of ideas is unique to evolution.

Explorations of science's self-correcting and collaborative nature deserve emphasis in the science classroom. Teachers who follow Nye's suggestions will help to nurture open-mindedness, critical thinking, and healthy skepticism in their students-all important characteristics for any scientist-without undermining their understanding of science, and of the nature of science. Rather than equivocating on the term theory à la Wade, teachers ought to focus on ensuring that students understand not only the important theories in the field of evolutionary biology-their history and their scope and their evidential bases-but also what a theory in science is and isn't. 


\section{Endnotes}

${ }^{a}$ Indeed, surveys routinely show that although acceptance of evolution is generally correlated with level of education, the correlation is reversed among the highly religious. In one survey, among those who believe that the Bible is the word of God, $31 \%$ of those with less than a high school education, but only $10 \%$ of those with a graduate degree, accepted human evolution (Reichard and Saari 2015).

${ }^{\mathrm{b}}$ Tennessee's Butler Act of 1925, for example, under which John Thomas Scopes was prosecuted, provided that "it shall be unlawful for any teacher in any of the Universities, Normals and all other public schools of the State which are supported in whole or in part by the public school funds of the State, to teach any theory that denies the story of the Divine Creation of man as taught in the Bible, and to teach instead that man has descended from a lower order of animals" (Larson 2003, p. 54).

\section{Competing interests}

The authors declare that they have no competing interests.

\section{Acknowledgments}

We wish to dedicate the present essay to the memory of Jack Friedman and Bernard Winograd, passionate defenders of the teaching of evolution.

Received: 23 March 2015 Accepted: 24 March 2015

Published online: 13 April 2015

\section{References}

Berbeco, M, McCaffrey, M, Meikle, E, \& Branch, G. (2014). Choose controversies wisely. The Science Teacher, 81(4), 8-9.

Branch, G, \& Mead, LS. (2008). "Theory" in theory and practice. Evolution Education and Outreach, 1(3), 287-289.

Branch, G, Scott, EC, \& Rosenau, J. (2010). Dispatches from the evolution wars: shifting tactics and expanding battlefields. Annual Review of Human Genetics and Genomics, 11, 317-338.

Gould, SJ. (1981). Evolution as fact and theory. Discover, 2, 34-7.

Gregory, TR. (2008). Evolution as fact, theory, and path. Evolution: Education and Outreach, 1(1), 46-52.

Larson, EJ. (2003). Trial and error: the American controversy over creation and evolution (3rd ed.). New York: Oxford University Press.

Nye, B. (2014). Undeniable: evolution and the science of creation. New York: St. Martin's Press.

Reichard, CS, \& Saari, IA. (2015). Why don't the highly educated believe in evolution? the bible believers effect. Skeptical Inquirer, 39(2), 42-45.

Ruse, M. (1984). Is there a limit on our knowledge of evolution? BioScience, $34(2), 100-104$

Wade, N. (2014). Bill Nye the Darwin guy. The Wall Street Journal, Sect A:11.

\section{Submit your manuscript to a SpringerOpen ${ }^{\circ}$ journal and benefit from:}

- Convenient online submission

- Rigorous peer review

- Immediate publication on acceptance

- Open access: articles freely available online

- High visibility within the field

- Retaining the copyright to your article

Submit your next manuscript at $>$ springeropen.com 